\title{
Scanning electron microscopic study of the tongue in golden-headed lion tamarins, Leontopithecus chrysomelas (Callithrichidae: Primates)
}

\author{
Carlos Henrique de F. Burity 1; Mirlene R. da Silva 1; Andreia M. de Souza 1; \\ Carla F. F. Lancetta ${ }^{1}$; Mildred F. Medeiros ${ }^{1} \&$ Alcides Pissinatti ${ }^{2}$
}

\author{
1 Setor de Morfologia, Unigranrio. Rua Professor José de Souza Herdy 1160, Duque de Caxias, 25071-202 Rio de Janeiro, \\ Rio de Janeiro, Brasil. E-mail: cburity@unigranrio.com.br \\ ${ }_{2}^{2}$ Centro de Primatologia do Rio de Janeiro, Fundação Estadual de Engenharia do Meio Ambiente. 20940-200 São \\ Cristovão, Rio de Janeiro. E-mail: pissinatticprj@terra.com.br
}

\begin{abstract}
Leontopithecus is the largest genus of Callithrichidae, occupying isolated remnants of the Atlantic Forest in Brazil. The objective of this study was to investigate the ultrastructure of the dorsum of the tongue of golden-headed lion tamarins. Tongues of ten adult lion tamarins kept in captivity at the Center of Primatology of Rio de Janeiro (CPRJFEEMA) were analyzed under scanning electron microscopy. The three vallate papillae were distributed in a V shape, and each papilla was surrounded by a deep sulcus and an external pad; the medial papilla showed a round shape and the lateral one was elliptical. The filiform papillae were shaped as a crown or as finger-like papillae, and were distributed throughout the tongue, including the margins, except for the posterior region. The fungiform papillae were scattered among the filiform papillae, in a disperse manner, from the apex to the lateral vallate papillae. The foliate papillae had a typical ultrastructure, with folds that ranged in number from 1 to 3 . With respect to vallate papillae, we identified the microridge and pore pattern on its surface. Further studies are required to confirm the hypotheses on the ultrastructural aspects described for golden-headed lion tamarins.
\end{abstract}

KEY WORDS. Lingual papillae; morphology; New World monkeys; SEM.

Leontopithecus (Lesson, 1820) is the largest genus of the Callithrichidae family, occupying isolated remnants of the Atlantic Forest in Brazil. The International Union for Conservation of Nature (IUCN) Species Survival Commission has considered the species of that genus to be critically endangered (CR) or endangered (EN) (Rosemberger \& Coimbra-Filho 1984, RYLANDs et al. 1993, IUCN 2007).

Several articles have been published in the scientific literature regarding the structure of the dorsal surface of the tongue in tetrapods: reptiles (IWASAKI et al. 1992, 1996, MoraIs et al. 1994, Beisser et al. 2004), birds (MARtinez et al. 2003, JACKOWIAK \& GODYNICKI 2005), and mammals (Fish et al. 1944, Chamorro et al. 1986, Agungrriyono et al. 1995, Emura et al. 2000). Although such studies in primates have concentrated on Old World Primates (SonNTAg 1921, ARvidson 1976, IWASAKI et al. 1992, EMura et al. 2002), some studies on neotropical primates may be found (Ledoux 1964, MACHIDA et al. 1967, IwASAKI et al. 1988, Matsukawa \& OKada 1994).

The structure of the tongue in neotropical primates has been insufficiently discussed in the literature; however, HeRshKovitz (1977) reported a briefing of the major aspects based mainly on the studies by SonNTag (1921) and Ledoux (1964).

So far, no study on the ultrastructure of the dorsal surface of the tongue in lion tamarins (Leontopithecus spp.) has been carried out. Therefore, this study aimed at examining the ultrastructure of the dorsal surface of the tongue in goldenheaded lion tamarins, examining those data in light of the current literature, and comparing them with those found in other animals, mainly primates.

\section{MATERIAL AND METHODS}

The tongues of ten adult golden-headed lion tamarins, Leontopithecus chrysomelas (Kuhl, 1820) were used in this study. Those animals were kept at the Center of Primatology of Rio de Janeiro (CPRJ). The facility is located $100 \mathrm{~km}$ northeast of the city of Rio de Janeiro, in a protected area of the Serra dos Órgãos mountain range. The animals were kept in groups in outdoor cages, being, thus, exposed to the Atlantic Forest conditions (e.g., sounds, temperature and rainfall). No animal was sacrificed in this study. The materials used in this study were obtained from animals that died due to different causes. Their tongues were conserved in 10\% formalin. Five small blocks were collected from the dorsal surface of the tongue with papillae at the following regions: anterior (apex), middle region and posterior region. The specimens were rinsed with $0.1 \mathrm{M}$ sodium cacodylate buffer at $\mathrm{pH}$ 7.3. Postfixation was made in $1 \%$ osmium tetroxide solution for two hours at $4^{\circ} \mathrm{C}$. The samples were dried in critical point dryer, using Balzers CPD-030. The 
coating, with gold, was made using Balzers SCD-040. The samples were examined in Scanning Electron Microscope JSM$6420,15 \mathrm{Kv}$ at Department PEMM/COPPE, Universidade Federal do Rio de Janeiro.

\section{RESULTS}

This study comprised 10 golden-headed lion tamarins with a mean age of 128 months, a mean weight of $602.2 \mathrm{~g}$, and a mean total length of $520 \mathrm{~mm}$ (without the tail).

Their tongues were elongated with a rounded flat apex. From the morphometric point of view, the tongues had a mean weight of $1.8 \mathrm{~g}$, a mean total length of $27.9 \mathrm{~mm}$, and a mean width at the base and apex of $12.6 \mathrm{~mm}$ and $7.1 \mathrm{~mm}$, respectively.

The dorsal surface of the tongue of golden-headed lion tamarins had four types of papillae: fungiform, filiform, vallate (one medial and two lateral), and foliate. The fungiform papillae projected among the filiform ones (Fig. 1.) in a disperse manner, from the lingual apex to the lateral vallate papillae. The flat tip of the fungiform papilla had a diameter of approximately 43 $\mu \mathrm{m}$ and epithelial cells similar to scales on its surface (Fig. 5). Under greater magnification, one can observe the elevated margins of the epithelial cells, their microridge pattern, and even the pore of the gustatory bud with an approximate diameter of $2 \mu \mathrm{m}$ on the surface of that papilla (Fig. 6).

The filiform papillae were scattered throughout the dorsal surface of the tongue, including the margins, except for the posterior region. Their ultrastructure was typical in the different regions of the tongue. They were similar to a crown or as fingerlike papillae, with a flat center and longer and more numerous prolongations pointing towards the posterior region, with approximately $200 \mu \mathrm{m}$ in width, and shorter and less numerous prolongations pointing towards the opposite margin (Fig. 1).

The medial vallate papilla had the round shape, was surrounded by a deep sulcus, and was located in the posterior region, which was devoid of other papillae. There were pads in the border of that papilla and separating it from the mucosa. The papilla as a whole, including the pad, measured approximately $1.46 \mathrm{~mm}$ (Fig. 2). Figure 3 depicts a lateral vallate papilla of approximately $2.0 \mathrm{~mm}$ in its greater length. It is also surrounded by a sulcus and pads, which separate the vallate papilla from the mucosa covered with filiform papillae.

The ultrastructure of the foliate papillae is typical, with 1 to 3 folds measuring approximately $600 \mu \mathrm{m}$ in extension. The quantity of folds varied in the same tongue when comparing the right and left sides, and the space between the folds varied from 240 to $360 \mu \mathrm{m}$ of width (Fig. 4).

\section{DISCUSSION}

The tongue of the golden-headed lion tamarin has a typical morphology among mammals, especially primates, with the following types of papillae: vallate, filiform, fungiform, and foliate. Regarding the general aspects, superior and inferior median sulci are observed, being in accordance with the findings in Callithrix (Erxleben, 1777) (SonNTAG 1921, Ledoux 1964), Saimiri (Voigt, 1831) (IWASAKI et al. 1988), and Saguinus (Hoffmannsegg, 1807) (MACHIDA et al. 1967).

As for the fungiform papillae, we confirmed the pattern already established in the literature, as reported by ARvidison (1976) and Mikkonen \& Sorvari (1985). Those authors reported depressions in the keratinized epithelium, where a microridge pattern, a supposedly system of microchannels and a central round pore may be detected. Such microridges have generated discussion in the literature regarding to their functionality. Some authors believe that the microridges could be linked to mucous retention, thus, making the papillae more efficient in regard to resistance to friction (MIKKONEN \& SORVARI 1985, IWASAKI et al. 1988). However, in the studied lion tamarins, we observed microridges in the fungiform papillae with gustatory pores on their surface, confirming the gustatory function instead of solely the mechanical function, according to the criteria of CHAMORRO et al. (1986). Although such fungiform papillae have microridges and a well-marked gustatory function, our study lacks morphological elements to support the friction hypothesis.

In the literature, the diameter of this pore has been reported as ranging from 1 to $7 \mu \mathrm{m}$ in mammals, such as rats, rabbits, simians, and humans (ARvidison 1976). In the studied lion tamarins, that diameter was approximately $2 \mu \mathrm{m}$, being similar to that of rodents. That pattern described for lion tamarins could be due to the conduction of particles diluted in saliva, allowing a better access to the pore, providing, thus, greater tasting efficiency. However, further functional studies are required to evaluate such hypothesis. In our study with SEM, we could not evidence the microvilli of the cells inside the gustatory pore, probably due poor fixation and conservation method (formalin). The same also happened to ARvidson (1976) with regard to rodents, with results similar to those of lion tamarins, thus confirming that difficulty.

Regarding the filiform papillae, authors have highlighted the complexity of keratinization and the different types of filiform papillae found in the dorsal surface of the tongue in mammals (КовауаShi \& Shimamura 1982, Emura et al. 2004). In our study, the filiform papillae showed a typical structure, i.e., with a finger-like or a crown-like shape, as cited by IWASAKI et al. (1992). On SEM, the papillae proved to be similar in the regions studied, which has also been reported by IWASAKI et al. (1988) in the squirrel monkey, and by MiкKONEN et al. (1987) in humans, rats, and pigs. However, Emura et al. (2002) observed differences between the apex and body regions of the tongue in Old World Primates, namely species of Cercopithecus (Linnaeus, 1758) and Macaca (Lacepede, 1799). Moreover, according to IWASAKI et al. (1988) and other authors, no microridges were observed in the cells of the filiform papillae, which is in accordance with our findings in lion tamarins.

The distribution pattern and shape of the vallate papillae have also been discussed in the literature. The distribution 

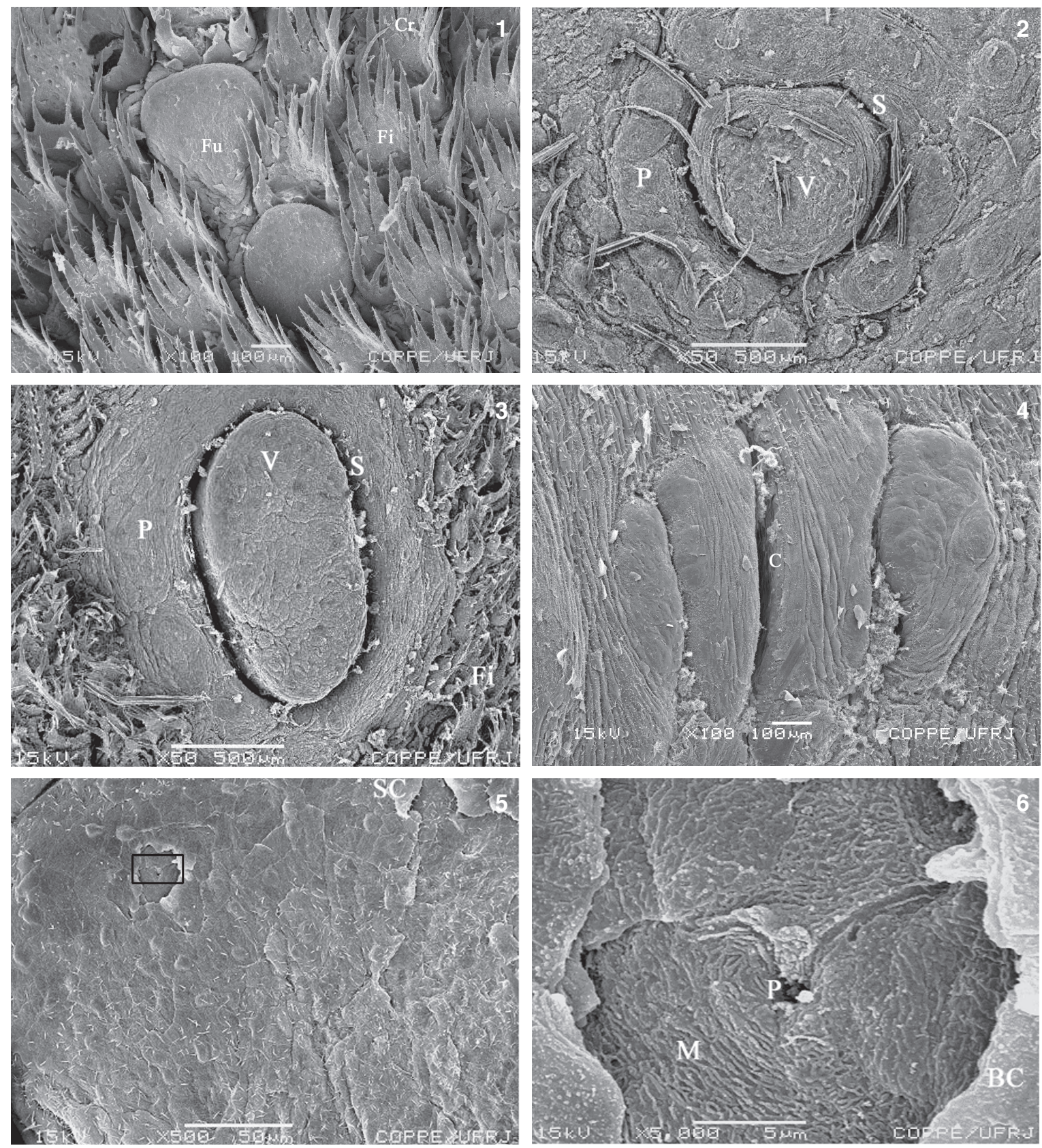

Figures 1-6. (1) SEM of the middle region of the dorsal surface of the tongue of the golden-headed lion tamarin. The fungiform papillae (Fu) can be seen among the filiform papillae (Fi). Note the longer and shorter prolongations of the filiform papilla similar to a crown or finger-like form (Cr). (2) SEM of the posterior region of the dorsal surface of the tongue of the golden-headed lion tamarin. The vallate papilla can be seen $(V)$ with its sulcus $(S)$ and pads $(P)$. Note the lack of filiform papillae in the surrounding mucosa. (3) SEM of the caudolateral region of the dorsal surface of the tongue in golden-headed lion tamarins. The vallate papilla can be seen ( $V$ ) with its sulcus $(\mathrm{S})$ and pads (P). Note the presence of filiform papillae (Fi) in the surrounding mucosa. (4) SEM of the caudolateral surface of the tongue of the golden-headed lion tamarin. The leaves of the papilla are separated by deep fold (C). (5) SEM of the surface of the fungiform papilla in the middle region of the body of the tongue in the golden-headed lion tamarin. Note the squamous epithelial cells shedding (SC). (6) Higher magnification of the area delimited in (e). Note the microridge pattern (M), the borders of the cells (BC), and the gustatory bud pore $(P)$. 
pattern in lion tamarins with three papillae in "V", the medial papilla with a distinctive shape from that of the lateral ones, is referred to in the literature as primitive (HershKOVITz 1977, KoBAyASHi et al. 2004). Such characteristics have also been observed in species of Callithrix (SonNtAg 1921, Ledoux 1964, MatsuKaWA \& OKADA 1994), Saguinus (Machida et al. 1967), and Saimiri (MatsukaWa \& OKada 1994, Iwasaki et al. 1988).

The number of vallate papillae in primates seems to have been well established in the literature (SONTAG 1921). Although the so-called triangular or in V pattern has been established, i.e., three vallate papillae, one medial (in the midline), some authors have reported different numbers: in the squirrel monkey, one papilla, according to IWASAKI et al. (1988); in the Japanese monkey, four papillae, according to IWASAKI et al. (1992), and the same triangular pattern, i.e., three papillae, according to Emura et al. (2002). KobaYAshi et al. (2004) have reported that the number of papillae varies according to the phylogenetic relation, in which Tupaia, Tamarins and Drills have a primitive pattern with three circumvallate papillae. Such statement supports our findings for lion tamarins, which have the triangular pattern, i.e., three vallate papillae.

The structure and number of folds in foliate papillae are also in accordance with that established in the literature. MACHIDA et al. (1967) have already discussed the absence of foliate papillae in prosimians and their prevalence in New and Old World Primates. The findings regarding the foliate papilla in neotropical primates indicate two to three folds in Callithrix spp. (Ledoux 1964, Matsukawa \& Okada 1994), four to five in Saimiri spp. (MatSUKAWA \& OKADA 1994), and five in lion tamarin (КоваYASH et al. 2004). However, in this study, we had the opportunity to observe animals with only one fold in one side of the tongue, and, in some cases, that fold bifurcated inside the tongue and had gustatory buds all over its surface (Fig. 7). Further studies are required to test the hypothesis of bifurcation, considering it a compensation for the single fold, in an attempt to increase the surface, and, thus, the number of gustatory buds. None of the previously cited studies, not even that by LIU \& LEE (1982) analyzing specifically those papillae in common laboratory species, reported that characteristic. Therefore, further studies are required to support those findings.

\section{ACKNOWLEDGMENTS}

The authors thank Ulysses Lins and Fernanda Abreu of the Institute of Microbiology, UFRJ, and Marcia Sader, PEMM/ COPPE/UFRJ, for their assistance in preparing the specimens and images of the SEM for this study. This study was supported by a grant from FAPERJ (C.H.F.B. E-26/170-873/00, E-26/170.286/07 and A.P. E-26/171-573/00) and PROPEP-UNIGRANRIO.

\section{LITERATURE CITED}

Agungrriyono, S.; J. Yamada; N. Kitamura; C. Nisa; K. Sigit \& Y. Yамамото. 1995. Morphology of the dorsal lingual papillae

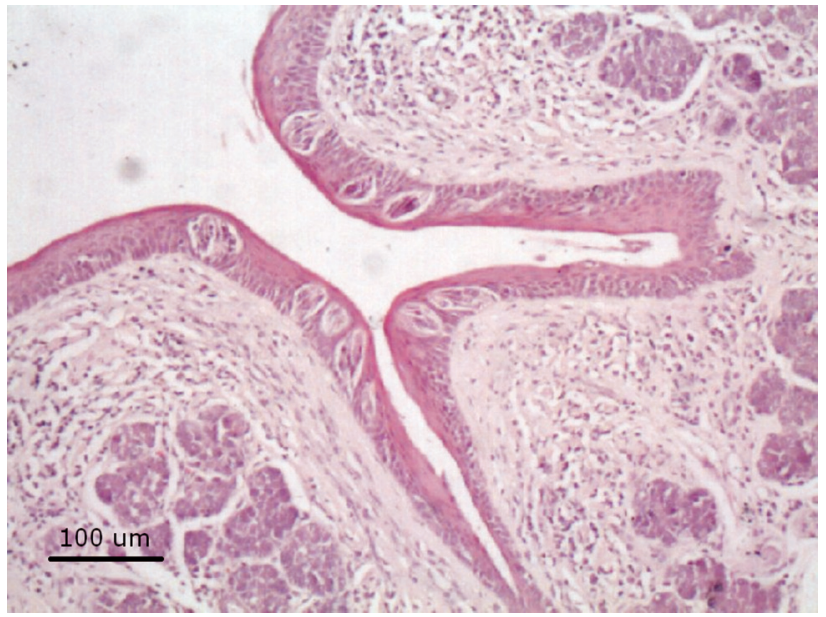

Figure 7. Photomicrography of the foliate papillae in the transversal plane showing the case of the specimen with only one fold, in one side of the tongue, that fold bifurcated inside the tongue and had gustatory buds all over its surface (objective 10x).

in the lesser mouse deer Tragulus javanicus. Journal of Anatomy 187: 635-640.

ARvidson, K. 1976. Scanning electron microscopy of fungiform papillae on the tongue of man and monkey. Acta Otalaryngology 81: 496-502.

Beisser, J.C.; P. Lemell \& J. Weisgram. 2004. The Dorsal Lingual Epithelium of Rhinoclemmys pulcherrima incisa (Chelonia, Cryptodira). Anatomical Record 277A: 227-235.

Chamorro, C.A.; P. Paz; J. Sandoval \& J.G. Fernandes. 1986. Comparative scanning electron microscopic study of the lingual papillae in two species of domestic mammals (Equus cabalus e Bos taurus). Acta Anatomica 125: 83-7.

Emura S.; A. Tamada; D. Hayakawa; H. Chen \& S. Shoumura. 2000. Morphology of the dorsal lingual papillae in the black rhinoceros (Diceros bicornis). Anatomia, Histologia, Embryologia 29: 371-374.

Emura, S.; D. Hayakawa; H. Chen \& S. Shoumura. 2002. Morphology of the dorsal lingual papillae in the Japanese macaque and Savanna monkey. Anatomia, Histologia, Embryologia 31: 313-316.

Emura, S.; D. Hayakawa; H. Chen \& S. Shoumura. 2004. Morphology of the lingual papillae in the tiger. Okajimas Folia Anatomica Japan 81: 39-43.

Fish, H.S.; P.D. Malone \& C.P. Richter. 1944. The anatomy of the tongue of the domestic Norway rat. I. The skin of the tongue: The various papillae: Their number and distribution. Anatomical Record 89: 429-40.

Hershrovitz, P.1977. Living New World Monkeys (Platyrrhini) with an introduction to Primates. Chicago, University of Chicago Press, vol. 1, XIII+1117p.

IWASAKI, S.; K. Miyata \& K. Kobayashi. 1988. Scanning-electron- 
microscopic study of the dorsal lingual surface of the squirrel monkey. Acta Anatomica 132: 225-229.

IWASAKI, S.; T. AsAmi; Y. Assami \& K. Kobayashi. 1992. Fine structure of the Dorsal epithelium of the tongue of the Japanese terrapin, Clemmys japonica (Chelonia, Emydinae). Archives of Histology and Cytology 55: 295-305.

IWASAKI, S.; C. Wanichanon \& T. Asami. 1996. Histological and ultrastructural study of the lingual epithelium of the juvenile Pacific ridley turtle, Lepidochelys olivacea (Chelonia, Chelonidae). Annals of Anatomy 178: 243-50.

IUCN 2007. 2007. IUCN Red List of Threatened Species. Available online at: http://www.iucnredlist.org [Accessed: 09/VII/2008].

JACKOWIAK, H. \& S. GODYNICKI. 2005. Light and Scanning Electron Microscopic Study of the Tongue in the White Tailed Eagle (Haliaeetus albicilla, Accipitridae). Annals of Anatomy 187: 251-259.

Kobayashi, K. \& S. Shimamura. 1982. Comparative anatomical observations of the tongue of Japanese long-fingered bat, Miniopterus schreibersi fuliginosus. Okajimas Folia Anatomica Japan 58: 923-932.

Kobayashi, K.; M. Kumamura; K. Yoshimura; M. Takahashi; J.H. Zeng; I. Kageyama; K. Kobayashi \& N. Hama. 2004. Comparative morphological studies on the stereo structure of the lingual papillae of selected primates using scanning electron microscopy. Annals of Anatomy 186: 525-530.

Ledoux, L.J. 1964. A língua do sagüi (Callithrix jacchus). Folia Clínica et Biológica 33: 23-41.

LiU, H.C. \& J.C. LeE. 1982. Scanning electron microscopic and histochemical studies of foliate papillae in the rabbit, rat and mouse. Acta Anatomica 112: 310-320.

Machida, H.; E. Perkins \& L. Giacometti. 1967. The Anatomical and Histochemical Properties of the tongue of primates. Folia Primatologica 5: 264-279.

Martinez, M.; M.A. Stefanini; F.E. Martinez; H.L. Guida; P.F.F. PINheiro; C.C.D. Almeida \& T.M. Segatelli. 2003. Morphological Study of the Tongue of Budgerigar (Melopsittacus undulatus). International Journal of Morphology 21: 117-122.

Matsukawa, N. \& S. OкаDA. 1994. Microvasculature of the lingual papillae in primates and insectivores-fungiform, vallate and foliate papillae. Okajimas Folia Anatomica Japan 71: 259-277.

Mikkonen, A.K. \& T.E. Sorvari. 1985. A Scanning Electron Microscopic Study of the Dorsal Surface of the Human Tongue. Acta Anatomica 123: 114-120.

Mikkonen A.K.; M. Hynynen \& P. Hyvonen. 1987. Filiform papillae of human, rat and swine tongue. Acta Anatomica 130: 280284.

Morais, J.O.R.; I. Watanabe \& B. Konig JR. 1994. Scanning electron microscopy of the lingual mucosa of the nine-banded armadillo, Dasypus novemcinctus. Annals of Anatomy 176: 357-361.

Rosenberger, A.L. \& A.F. CoImbra-Filho. 1984. Morphology, taxonomic status and affinities of the Lion Tamarins, Leontopithecus (Callitrichinae, Cebidae). Folia Primatologica 42: 149-179.

Rylands, A.B.; A.F. Coimbra-Filho \& R.A. Mittermeier. 1993. Sistematics, geographic distribuiton, and some notes on the conservation status of the Callitrichidae, p. 11-77. In: A.B. Rylands (Ed.) Marmosets and tamarins systematics, behaviour, and ecology. Oxford, Oxford University Press, XVI+396p.

SonNTAG, C.F. 1921. The Comparative Anatomy of the Tongues of the Mammalia. II. Family 1. Simiidae. Proccedings of Zoological Society 1: 1-29.

Submitted: 10.VII.2008; Accepted: 08.IV.2009.

Editorial responsibility: Lucélia Donatti 